\title{
FABRICATION AND CHARACTERIZATION OF BREAST PHANTOM BASED ON GELATIN-GLYCERIN-TIO 2 FOR A CONTINUOUS-WAVE DIFFUSE OPTICAL TOMOGRAPHY
}

\author{
N. Ukhrowiyah ${ }^{1 a^{*}}$, D. Hikmawat ${ }^{1 \mathrm{~b}}$, M. Yasin ${ }^{1 \mathrm{c}}$, and R. Yuni ${ }^{1 \mathrm{~d}}$ \\ ${ }^{1}$ Department of Physics, Faculty of Science and Technology, Universitas Airlangga, Surabaya 60115, Indonesia. \\ Email: nurilukhrowiyah@fst.unair.ac.id ${ }^{\mathrm{a}}$; dyah-hikmawati@fst.unair.ac.id ${ }^{\mathrm{b}}$; $\quad$ yasin@fst.unair.ac.idc; \\ risayuniastuti@gmail.com ${ }^{\mathrm{d}}$ \\ *Corresponding Author's Email: nurilukhrowiyah@fst.unair.ac.id \\ Submitted: $27^{\text {th }}$ December $2018 \quad$ Accepted: $9^{\text {th }}$ July 2019 \\ Published: $30^{\text {th }}$ November 2019
}

DOI: https://doi.org/10.22452/mjs.sp2019no3.6

\begin{abstract}
In this paper, the fabrication and characterization of breast phantom based on gelatin-glycerin- $\mathrm{TiO}_{2}$ as breast simulation tissue is proposed and investigated. A sample preparation was done by mixing 3 grams of gelatin per $10 \mathrm{ml}$ of saline. The sample was added with glycerin with four different concentrations of $85 \%, 90 \%, 95 \%$ and $100 \%$ as sample A, B, C and $\mathrm{D}$ respectively. The sample $\mathrm{D}$ is optimum as it was able to survive at room temperature for 126 hours. Subsequently, sample D was added by $\mathrm{TiO}_{2}$ given variations of 0.010 grams, 0.015 grams, 0.020 grams and 0.025 grams. All samples were tested for its homogeneity and absorption coefficient using Continuous Wave Diffuse Optical Tomography (CW-DOT) with laser wavelengths of 780, 808 and $830 \mathrm{~nm}$. The results showed that the optimum sample characterization was achieved at wavelength of $830 \mathrm{~nm}$ with $\mathrm{TiO}_{2}$ variation of 0.025 grams. The absorption coefficient breast phantom was obtained at $0.167 \mathrm{~mm}^{-1}$. Phantom based on gelatinglycerin- $\mathrm{TiO}_{2}$ can be applied as material replacement of breast for test object in CW-DOT.
\end{abstract}

Keywords: Breast phantom, gelatin, glycerin, titanium dioxide, and optical tomograph

\section{INTRODUCTION}

Based on 2013 Basic Health Research data, the prevalence of tumors (benign and malignant) in Indonesia has reached 1.4 per 1.000 population or about 330 people. Breast and cervix are types of cancer that most prevalent with highest mortality. Most cases (50\%) and breast cancer deaths (58\%) allegedly are due to lack of early detection instrument of breast cancer and health care. Approximately $68.6 \%$ of women who are infected by Carcinoma mammae are detected after reaching an advanced stage of local (III A and III B), while at an early stage (I and II) only $22.4 \%$ are detected (Azamris, 2006).

One of techniques for early detection of carcinoma mammae that is easily accessible by public is the Near Infrared- 
diffuse optical tomography (NIR-DOT). The advantage of NIR-DOT lies on its radiation source used which is in the form of Near Infrared (NIR) that is non-invasive and nonionizing (Kemsley et al., 2008). Unfortunately, a direct exposure to visible light or NIR on mammae tissue often causes concerns in most women. Therefore, an effort to build early detection equipment with NIR-DOT is needed, such as phantom which is a material replacement to simulate the presence of Carcinoma mammae. Phantom is defined as an object that acts as a simulation to replicate the characteristics of human or animal tissue (Pogue et al., 2006). Phantom can be made of various materials including gelatin, lipid, resins, polyester and polyurethane.

Breast phantom which is based on gelatin has several advantages namely its optical characteristics resemble normal breast tissue (de Grand et al., 2006), it is relatively inexpensive and easy to obtain and non-toxic (Lualdi, 2001). However, gelatin has life cycle that tends to be short and easily damaged, so it is necessary to add glycerin to improve durability. Based on an article written by Firbank and Delphy (1993), phantom materials that can be used to approximate the characteristics of the tissue must have optical characteristics that are scattering and absorbing. These scattering and absorbing characteristics can be determined by adding $\mathrm{TiO}_{2}$ material. $\mathrm{TiO}_{2}$ can produce a stable scattering spectrum (Jiang, 2003). Based on the reasons aforementioned, this study is expected to shed light on the breast phantom which is durable, resistant to fungi or microbes while having the characteristics of normal breast tissue that can be evaluated from its physical, mechanical, thermal and optical characteristics.

\section{MATERIALS AND METHODS}

The materials used in this research include gelatin (cow skin gelatin, Guangdong, China), glycerin (P\&G Chemical, Malaysia), $\mathrm{TiO}_{2}$ powder (Titanium Dioxide, E. Merck, 64271 Darmstadt, Germany), $\mathrm{NaCl}$ powder, and distilled water. The method used to produce test sample is by mixing all the ingredients to obtain a homogeneous test sample. The test sample consists of two variations, namely variations in the composition of glycerin and variations of $\mathrm{TiO}_{2}$. There were several steps taken to get the sample. First, 3 grams of powdered gelatin and $10 \mathrm{ml}$ of saline were mixed. Alloy gelatin and saline solution can be obtained by homogeneous stirring at $35^{\circ} \mathrm{C}$ to $40^{\circ} \mathrm{C}$ for 35 minutes or until the solution becomes homogeneous. Then glycerin with concentrations of $85 \%$, $90 \%$, $95 \%$, and $100 \%$ was added to the homogenized solution of gelatin, as shown in Table 1 . The ratio for gelatin solution: glycerin is 3: $1(\mathrm{v} / \mathrm{v})$. The gelatin solution and glycerin were mixed for 10 minutes and stirred at $35^{\circ} \mathrm{C}-40^{\circ} \mathrm{C}$. Next, the sample was poured into four $40 \mathrm{ml}$ plastic pot-shaped cylinder with a diameter of $36 \mathrm{~mm}$. The fourth test sample was placed in the room temperature $\left(\mathrm{T}=27^{\circ} \mathrm{C}\right)$ for several days, then its durability properties were observed. After obtaining the most durable test samples, the second variation was done which was the addition of $\mathrm{TiO}_{2}$ variation of 0.01 grams - 0,025 grams. $\mathrm{TiO}_{2}$ mixing process took about 60 minutes. Then the sample was poured into a cylindrical plastic pot with a diameter of $27 \mathrm{~mm}$.

The structure of $\mathrm{TiO}_{2}$ was determined by conventional X-ray diffraction (Philips PW 1820 powder 
diffractometer with an accuracy of 0.0158 in $2 \theta$ using $\mathrm{CuKa}$ radiation). The characterization of the samples was done by doing the physical characterization test, the FTIR test, the DSC test, the materials homogeneity test and the material absorption coefficient $\left(\mu_{\mathrm{a}}\right)$ test. The physical characterization was performed to determine the durability and the modulus of elasticity, so that samples can be used optimally. Gelatin is not stable in aqueous solvent systems and undergoes a progressive hydrolytic degradation lowering its molecular weight and consequently decreasing useful physical properties. Hydrolysis of the gelatin depends on the temperature, $\mathrm{pH}$ of the system and to a lesser extent on the nature of the other solutes that can be present. The activity of fungi is to break the polymer chains of gelatin and use it to grow and affect the physical characteristics of the samples. This test was used to observe the durability of the samples towards the environment. The durability test was performed in an open room at room temperature. The preservation period was measured from the setting of the sample to the growth of fungi in the sample. The pressure test was performed to analyse the sample's modulus of elasticity. The FTIR test was performed to determine the functional groups of each ingredient. The DSC test was carried out on the effect of temperature on test material to ensure that during the tomographic test, the sample was not degraded due to the heat radiation of the laser. The next test was the homogeneity and optical properties test which was performed by measuring the absorption coefficient value $\left(\searrow_{a}\right)$ of samples by using homemade continuous wave diffuse optical tomography, CWDOT (Ukhrowiyah, 2015). In measuring the absorption coefficient value $\left(\searrow_{\mathrm{a}}\right)$, the sample with $\mathrm{TiO}_{2}$, was made by five thickness variations including $4 \mathrm{~mm}$, $8 \mathrm{~mm}, 12 \mathrm{~mm}, 16 \mathrm{~mm}$ and $20 \mathrm{~mm}$.

\section{RESULTS AND DISCUSSION}

\subsection{Result of Physical Characterization Test}

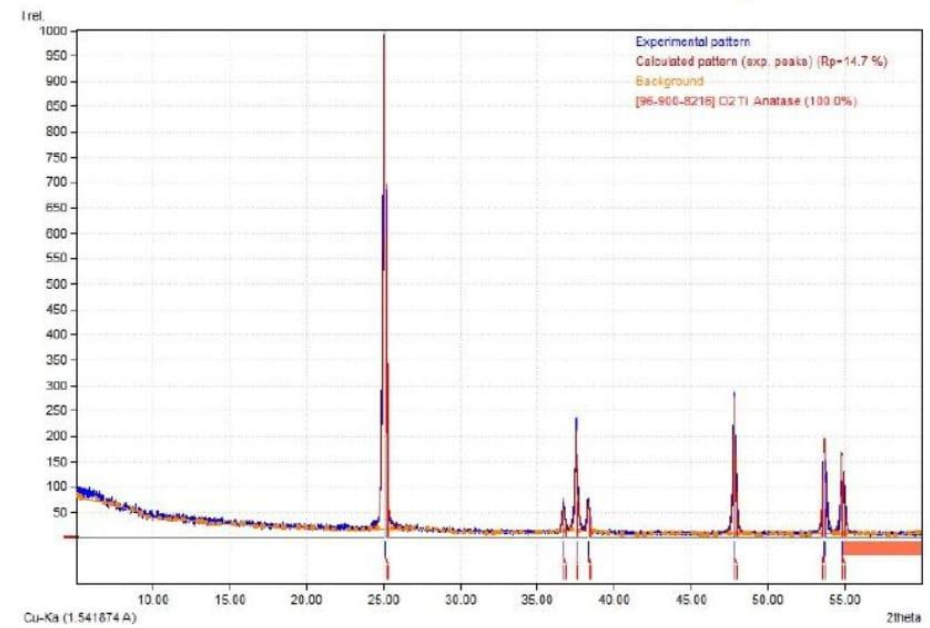

Fig 1. Diffractogram of $\mathrm{TiO}_{2}$ 
The XRD pattern was recorded at the angular range of $2 \theta=5^{\circ}-60^{\circ}$. Figure 1 shows the X-Ray diffractometry, which indicates that the structure of $\mathrm{TiO}_{2}$ is anatase phase, indexed by JCPDS card no. 96-900-8261, the strongest peak is (101). The UV-Vis spectroscopy identification that $\mathrm{TiO}_{2}$ increased absorption is shown in Figure 2 and Table 1. XRD test and UV/Vis Test showed that the addition of $\mathrm{TiO}_{2}$ enhance the absorbance of the sample for all wavenumbers, especially at $780 \mathrm{~nm}, 808 \mathrm{~nm}$, and $830 \mathrm{~nm}$.

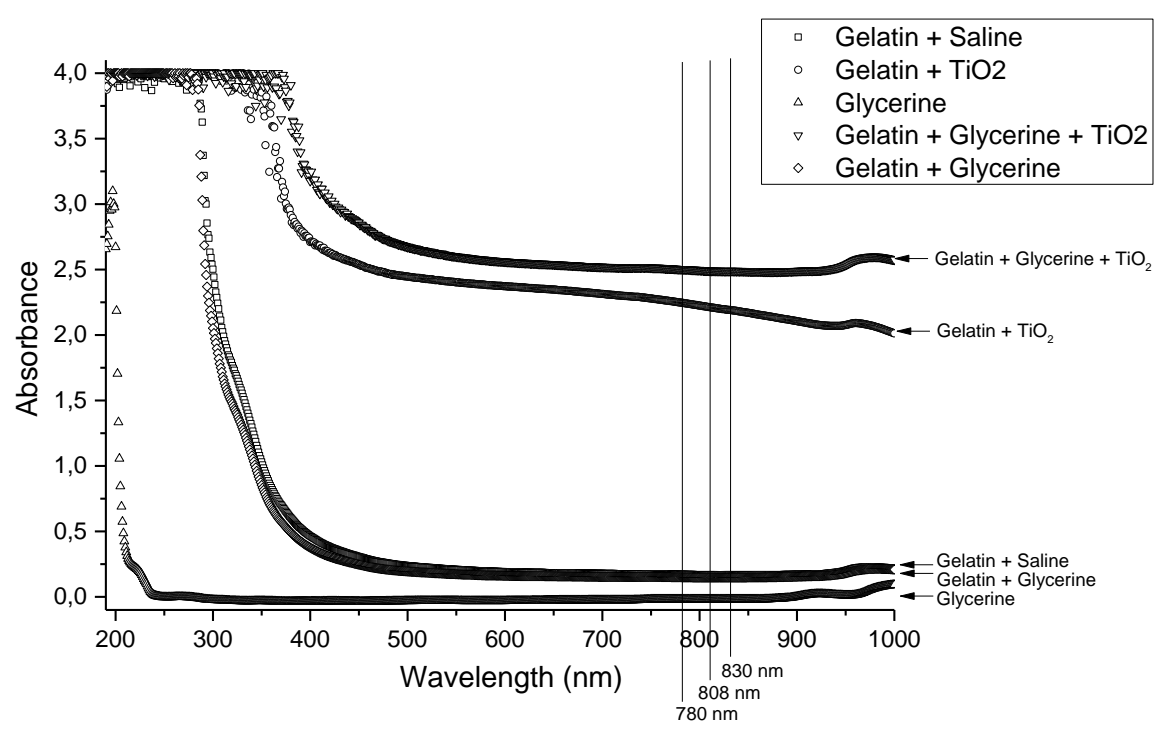

Figure 2. UV-Vis spectrogram of samples of glycerin, gelatin-glycerin, gelatin-saline, Gelatine- $\mathrm{TiO}_{2}$, gelatin-glycerin- $\mathrm{TiO}_{2}$

Table 1. Absorbance of Samples glycerin, gelatin-glycerin, gelatin-saline, Gelatine- $\mathrm{TiO}_{2}$, gelatin-glycerin- $\mathrm{TiO}_{2}$

\begin{tabular}{cccccc}
\multirow{2}{*}{$\begin{array}{c}\text { Wavelength } \\
(\mathrm{nm})\end{array}$} & $\begin{array}{c}\text { Gelatin }+ \\
\text { Saline }\end{array}$ & $\begin{array}{c}\text { Gelatin }+ \\
\mathrm{TiO}_{2}\end{array}$ & Glycerine & $\begin{array}{c}\text { Gelatin }+ \\
\text { Glycerine }+ \\
\mathrm{TiO}_{2}\end{array}$ & $\begin{array}{c}\text { Gelatin }+ \\
\text { Glycerine }\end{array}$ \\
\cline { 2 - 6 } & 0.172 & 2.248 & -0.02 & 2.504 & 0.15 \\
780 & 0.169 & 2.215 & -0.019 & 2.494 & 0.147 \\
808 & 0.169 & 2.192 & -0.019 & 2.489 & 0.148 \\
\hline
\end{tabular}




\subsection{Result of Physical Characterization Test}

The synthesis result of gelatinglycerin composite samples is shown in Figure 3. Figure $3 \mathrm{~A}$ shows the samples of gelatin-glycerin sample without $\mathrm{TiO}_{2}$ while Figure 3B shows the samples of gelatinglycerin which was added by $\mathrm{TiO}_{2}$. The

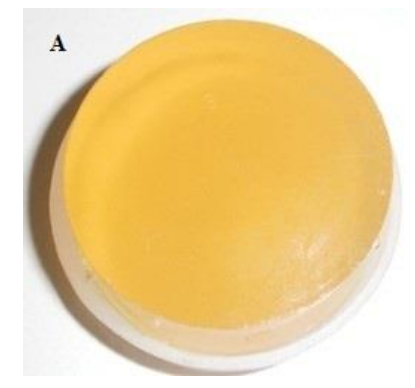

gelatin-glycerin sample without $\mathrm{TiO}_{2}$ was tested for its durability. The observations were done at room temperature $\left(29.7^{\circ} \mathrm{C}\right)$ and air humidity of $57 \%$ to know the growth of fungi. Table 1 shows data of durability test on the concentration variations of glycerin used. Whereas, the presence of fungi that grew in the sample is shown in Figure 4.

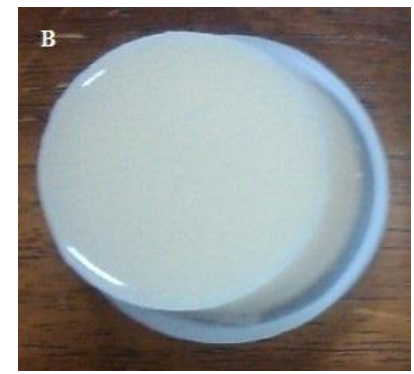

Figure 3. Gelatin-glycerin samples (a) without the addition of $\mathrm{TiO}_{2}$ (b) the addition of 0.01 grams $\mathrm{TiO}_{2}$

Table 2. Durability Test Results of Gelatin-glycerin Phantom at room temperature $\left(27^{\circ} \mathrm{C}\right)$

$\begin{array}{ccc}\text { Type of sample } & \begin{array}{c}\text { Variation of Glycerin } \\ \text { Concentration }(\%)\end{array} & \begin{array}{c}\text { Preservation } \\ \text { (Hour) }\end{array}\end{array}$

\begin{tabular}{lcc}
\hline A & 85 & 108 \\
B & 90 & 108 \\
C & 95 & 72 \\
D & 100 & 126 \\
\hline
\end{tabular}

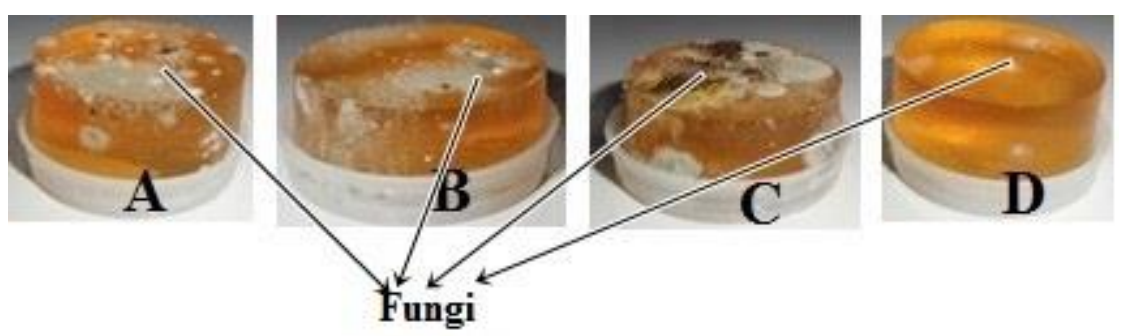

Figure 4. Durability Test Results of Gelatin-glycerin Samples at $27^{\circ} \mathrm{C}$ 
Based on the Table 2, it can be seen that the higher the concentration of glycerin, the more durable sample. Samples with addition of glycerin with concentration of $100 \%$ could last for 126 hours. It is also shown that in the sample $\mathrm{D}$, the number of fungi found is the least. The most durable sample (D) was used for calibration of NIRDOT via homogeneity test and material absorption coefficient $\left(\mu_{a}\right)$ test. Its sample was added $\mathrm{TiO}_{2}$ at different concentrations, as shown in Figure 3B. Even though, there was a decrease on Sample $(C)$, the trend of the durability is increase when the concentration of glycerin is increase as well.
The second physical characterization determines the modulus of elasticity. The test was done by pressuring the sample with force measurement device (IMADA). The result of the test is shown in Table 3 and Figure 4. Based on Table 3 and Figure 5, it can be shown that the higher the glycerin concentration added to the gelatin solution, the lower the modulus of elasticity. The elastic modulus values of the four samples are still higher compared to the value obtained by the previous researches whose magnitude was between $0.167 \mathrm{KPa}$ and 29 $\mathrm{KPa}$ (Mc Kee, 2011).

Table 3. Result of compressive strength test analysis.

\begin{tabular}{cccc}
\hline Sample & $\begin{array}{c}\text { Concentration of } \\
\text { Glycerin }(\boldsymbol{\%})\end{array}$ & Force, F (N) & $\begin{array}{c}\text { Modulus Elasticity, E } \\
(\text { KPa) }\end{array}$ \\
\hline A & 85 & 44.32 & $80.29 \pm 5.70$ \\
B & 90 & 30.75 & $61.01 \pm 4.61$ \\
C & 95 & 29.2 & $66.12 \pm 7.57$ \\
D & 100 & 22.03 & $45.89 \pm 3.58$ \\
\hline
\end{tabular}

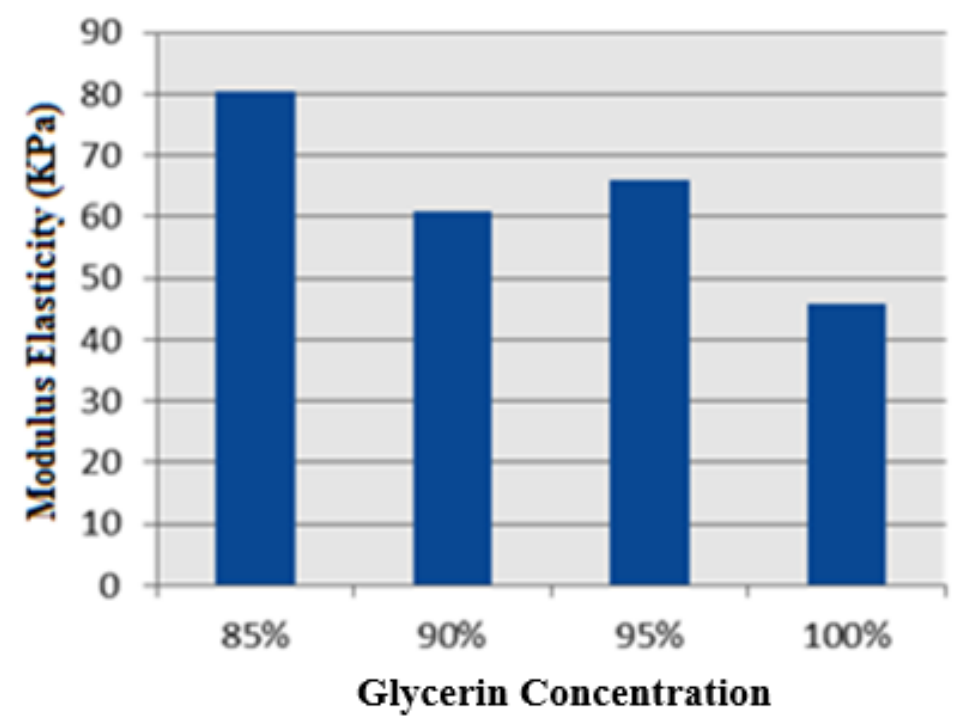

Figure 5. Graph on relationship between the elasticity modulus of gelatine-glycerin with concentration glycerin 


\subsection{Result of FTIR Test}

The FTIR characterization test results performed on samples of gelatine, glycerin, gelatine-glycerin, and gelatineglycerin- $\mathrm{TiO}_{2}$ are shown in Figure 6. The FTIR analysis was conducted by matching the wave absorption unique area to each functional group. Results of functional groups along with local uptake obtained by
FTIR spectra are shown in Table 4.

Table 4 shows that the typical functional group of gelatin, namely $\mathrm{N}-\mathrm{H}$, still appears on FTIR of gelatin-glycerin sample and gelatin-glycerin- $\mathrm{TiO}_{2}$ phantom spectra. In addition, the typical functional group of glycerin, namely $\mathrm{C}-\mathrm{OH}$ (primary alcohol and secondary alcohol), also appears.

Table 4. Results of FTIR Spectrum Analysis

\begin{tabular}{|c|c|c|c|c|}
\hline \multirow{2}{*}{ Functional Group } & \multicolumn{4}{|c|}{ Wave Number $\left(\mathrm{cm}^{-1}\right)$} \\
\hline & Gelatin & Glycerin & $\begin{array}{c}\text { Gelatin- } \\
\text { Glycerin } \\
\mathbf{1 0 0 \%} \\
\end{array}$ & $\begin{array}{l}\text { Gelatin-Glycerin } \\
100 \%-\mathrm{TiO}_{2} 0,025 \mathrm{~g}\end{array}$ \\
\hline $\begin{array}{l}\text { Stretching Vibration OH } \\
\text { (bending H intermolecular) }\end{array}$ & 3398.69 & 3396.6 & 3406.4 & 3396.76 \\
\hline Stretching Vibration C-H & - & 1641.48 & - & 1647.26 \\
\hline $\begin{array}{l}\text { Stretching Vibration C-OH } \\
\text { (primary alcohol) }\end{array}$ & - & 1111.03 & 1111.03 & 1111.03 \\
\hline $\begin{array}{l}\text { Stretching Vibration C-OH } \\
\quad \text { (secondary alcohol) }\end{array}$ & - & 1043.52 & 1043.52 & 1043.52 \\
\hline Bending Vibration N-H & 1656,91 & - & 1651.12 & 1647.26 \\
\hline Deformation Vibration N-H & 1545,03 & - & - & - \\
\hline Fuctional group of carboxyl $\mathrm{COO}^{-}$ & 1336,71 & - & - & - \\
\hline Stretching Vibration $\mathrm{C}=\mathrm{O}$ & - & 1641.68 & 1651.12 & 1647.26 \\
\hline Vibration $\mathrm{C}=\mathrm{N}$ & - & - & - & - \\
\hline
\end{tabular}



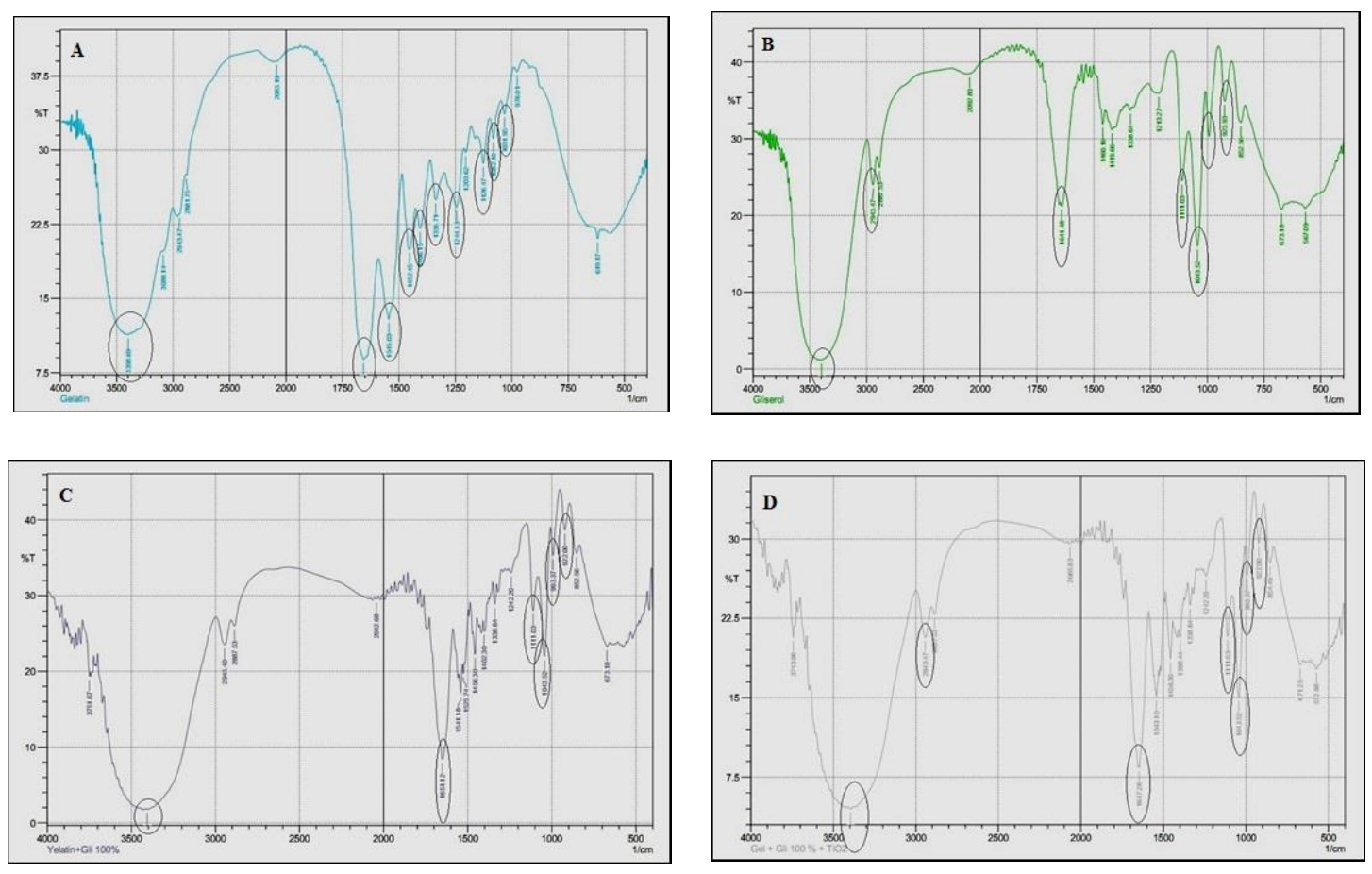

Figure 6. FTIR spectra of (A) gelatin, (B) Glycerin, (C) gelatin-glycerin, and (D) gelatin-glycerin- $\mathrm{TiO}_{2}$.

Figure 6A shows the FTIR spectrum of gelatin. This spectrum shows the gelatin typical functional group absorption area at wavenumber $3398.69 \mathrm{~cm}^{-1}$ which is a stretching vibration of $\mathrm{OH}$ (intermolecular $\mathrm{H}$ bond). The intermolecular $\mathrm{H}$ bond is a strong absorber at a wavelength $3398.69 \mathrm{~cm}^{-1}$ and has sharp peaks. This indicates the purity level of gelatin. In the region of wave number $1656.91 \mathrm{~cm}^{-1}$, there was an absorption of bending N-H functional group. The N-H function group is a typical functional group of gelatin. The area of wavenumber absorption of $1545.03 \mathrm{~cm}^{-1}$ and $1452.45 \mathrm{~cm}^{-1}$ is the $\mathrm{N}-\mathrm{H}$ deformation vibration and $\mathrm{C}-\mathrm{H}$ deformation vibration (Mistry, 2009). Wave number $1336.71 \mathrm{~cm}^{-1}$ is the absorption area of carboxyl (COO-) proline gelatin which is the characteristic of type 1 collagen.
Figure 6B represents the FTIR spectrum of glycerin or glycerol. Glycerin is an alcohol derivative that has several spectra of typical absorption regions. The absorption area at wavenumber of $3396.76 \mathrm{~cm}^{-1}$ is the absorption of stretching functional group $\mathrm{OH}$ (intermolecular $\mathrm{H}$ bond). At wavenumber $2943.47 \mathrm{~cm}^{-1}$, there was absorption of $\mathrm{C}-\mathrm{H}$ stretching functional groups. Wavenumber $1641.48 \mathrm{~cm}^{-1}$ is the absorption area of the functional group $\mathrm{C}=\mathrm{O}$ (intermolecular $\mathrm{H}$ bond). Wavenumber $1111.03 \mathrm{~cm}^{-1}$ is the absorption of stretched $\mathrm{C}-\mathrm{OH}$ functional group. The $\mathrm{C}-\mathrm{OH}$ function group is one of the functional groups of primary alcohol (Mistry, 2009). The absorption area at wavenumber $1043.52 \mathrm{~cm}^{-1}$ is the absorption of the $\mathrm{C}-\mathrm{OH}$ functional group (secondary alcohol) stretching vibration. 
Figure 6C shows the results of the FTIR spectrum of gelatin-glycerin sample (sample D). Based on the spectrum produced, there are several absorption areas that are characteristic of the main ingredients used, such as the wavenumber $3406.4 \mathrm{~cm}^{-1}$ which is an $\mathrm{OH}$ functional group (intermolecular $\mathrm{H}$ bond) of all the main ingredients that have $\mathrm{OH}$ functional groups. In the FTIR spectrum, wavenumber 1651.12 $\mathrm{cm}^{-1}$ is the absorption area of the functional group $\mathrm{C}=\mathrm{O}$, the curve vibration which is a characteristic of primary amide uptake. The primary amide functional group is a typical functional group of gelatin. Wavenumbers $1111.03 \mathrm{~cm}^{-1}$ and $1043.52 \mathrm{~cm}^{-1}$ are absorption areas of stretching vibration of C$\mathrm{OH}$ functional groups which are characteristic of glycerin namely primary alcohol and secondary alcohol.

Figure 6D shows the results of FTIR spectrum of gelatin-glycerin- $\mathrm{TiO}_{2}$ sample (sample D which is added $0.025 \mathrm{~g} \mathrm{TiO}_{2}$ ). Based on the resulting spectrum, there are several absorption areas that show the characteristics of the main materials of gelatin and glycerin. The $\mathrm{OH}$ (intermolecular) functional group absorbs at wavenumber $3396.76 \mathrm{~cm}^{-1}$ which experienced a shift from the main material absorption area before mixing. At wavenumber $1647.26 \mathrm{~cm}^{-1}$, the typical functional group of gelatin is the functional group $\mathrm{C}=\mathrm{O}$ the buckling vibration also still appeared. Similar to the gelatin characteristic absorption area, at wavenumbers $1111.03 \mathrm{~cm}^{-1}$ and $1043.52 \mathrm{~cm}^{-1}$, in the area of absorption of $\mathrm{C}-\mathrm{OH}$ functional groups curvature vibrations (primary alcohol and secondary alcohol) which are characteristic of glycerin, also still appeared.

\subsection{Result of Differential Scanning Calorimetric Test (DSC)}

The DSC test in this study aimed to determine the acceptable temperature of samples so that the samples are not degraded when they are irradiated by the laser. In this DSC test, sample D was used and heated in $40-70^{\circ} \mathrm{C}$ temperature range, and the temperature increment was $5^{\circ} \mathrm{C}$ per minute. Temperatures used in the DSC test were based on the characterization of laser in which laser output generates temperature of $20^{\circ} \mathrm{C}$ every 10 minutes and the test process was performed for \pm 10 minutes for one sample. The thermogram of synthesized gelatine-GA- $\mathrm{TiO}_{2}$ is shown in Figure 7.

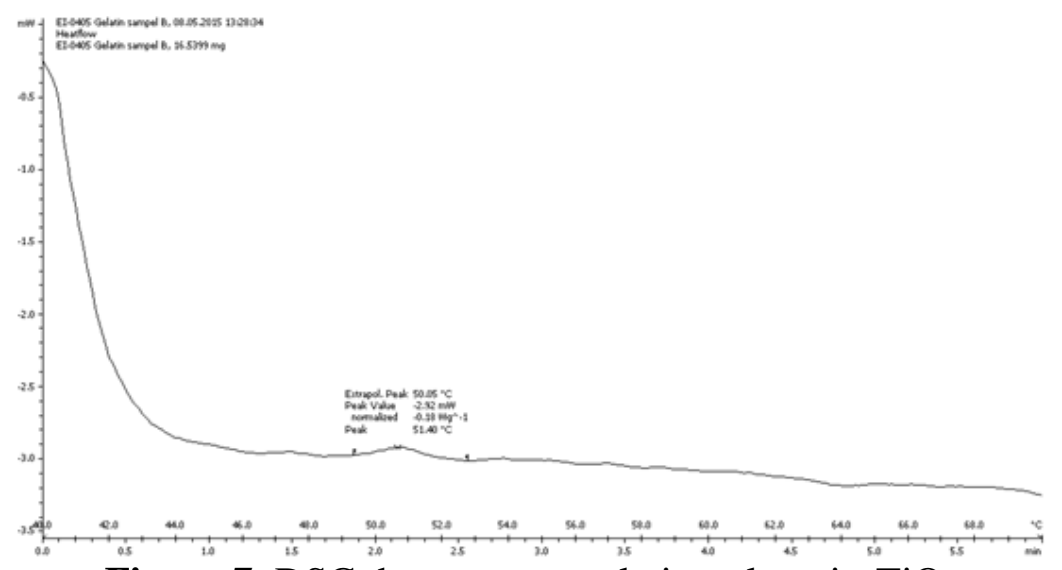

Figure 7. DSC thermogram gelatine-glycerin- $\mathrm{TiO}_{2}$ 
Based on the graph in Figure 7, characterization results showed that there was no change in physical reaction in the sample. This was indicated by the absence of melting points, glass transition, and crystallinity at $40^{\circ} \mathrm{C}-70^{\circ} \mathrm{C}$. Based on these results, gelatin-glycerin- $\mathrm{TiO}_{2}$ phantom, which was given a direct exposure at $40^{\circ} \mathrm{C}$ $70^{\circ} \mathrm{C}$, did not experience exothermic reactions or endothermic reactions. The main ingredients, gelatin has a melting point at $30^{\circ} \mathrm{C}$ to $40^{\circ} \mathrm{C}$ while $\mathrm{TiO}_{2}$ has a melting point at $1855^{\circ} \mathrm{C}$. The addition of $\mathrm{TiO}_{2}$ to the gelatin-glycerin sample can increase resistance to its thermal characteristics. This indicates that the gelatin-glycerin- $\mathrm{TiO}_{2}$ phantom can be applied optimally as a breast phantom without concerns of any exothermic or endothermic reactions due to changes in temperature.

\subsection{Result of Homogeneity Test}

The homogeneity test was conducted to determine the homogeneity of gelatineglycerin- $\mathrm{TiO}_{2}$ phantom. In this test, the sample $\mathrm{D}$ was added by $\mathrm{TiO}_{2}$ with variations of $0.01 ; 0.015 ; 0.02$ and 0.025 gram. The laser with 3 variations of NIR wavelengths, which are $780 \mathrm{~nm}, 808 \mathrm{~nm}$ and $830 \mathrm{~nm}$, were incorporated to this sample by using CWDOT. Figure 8 shows the relationship between output Voltage (V) to source position for sample $\mathrm{D}+\mathrm{TiO}_{2} 0.025$ gram at wavelengths of $780 \mathrm{~nm}, 808 \mathrm{~nm}$ and $830 \mathrm{~nm}$. The sample will have a good homogeneity, if the position between sources that have the same distance to the detector produce the same output voltage. Under these conditions, the graph of the output voltage generated by the source position has a trend line or a Ushaped pattern. Based on Figure 8, it can be seen that all wavelength variations have a trend line or a similar U-shaped pattern.
Based on Figure 8 , the optical output voltage at $\lambda=808 \mathrm{~nm}$ generates maximum value. However, the power generated by the wavelength of $808 \mathrm{~nm}$ is too big $(180 \mathrm{~mW})$. One of advantages of DOT in the diagnosis of breast cancer is that the laser source used is a low-power laser that is safe and non-invasive in analyzing the internal structure of human tissue. Therefore, the light source with $\lambda=808 \mathrm{~nm}$ $(180 \mathrm{~mW})$ is not suitable to be used in the diagnosis of breast cancer. Based on this analysis, the absorption coefficient test used $\lambda=830 \mathrm{~nm}$ because it has much lower power $(30 \mathrm{~mW})$.

Figure 9 shows the relationship between transmitted intensity of laser after passing samples as a.function mass of $\mathrm{TiO}_{2}$ at wavelengths of $780 \mathrm{~nm}, 808 \mathrm{~nm}$ and 830 $\mathrm{nm}$. Output voltage value was generated by the sample with the addition of 0.025 grams $\mathrm{TiO}_{2}$ which yields its minimum value. Output voltage (V) accounts for the transmitted laser intensity after passing through the sample, the smaller the value of the optical output voltage, the greater the intensity absorbed by the sample. The position number DOT laser source device was selected at the 9th position because it is the furthest from the source. Based on the results shown in Figure 9, the absorption coefficient test was carried out on samples with the addition of 0.025 grams $\mathrm{TiO}_{2}$. Laser with $\lambda=808 \mathrm{~nm}$ showed a decrease in the value of the output voltage that is significant compared to the value of the output voltage at $\lambda=780 \mathrm{~nm}$ and $\lambda=830 \mathrm{~nm}$, but the generated power was too big $(180 \mathrm{~mW})$, so that the coefficient test absorbency used laser with $\lambda=830 \mathrm{~nm}$, which generated 30 $\mathrm{mW}$. 


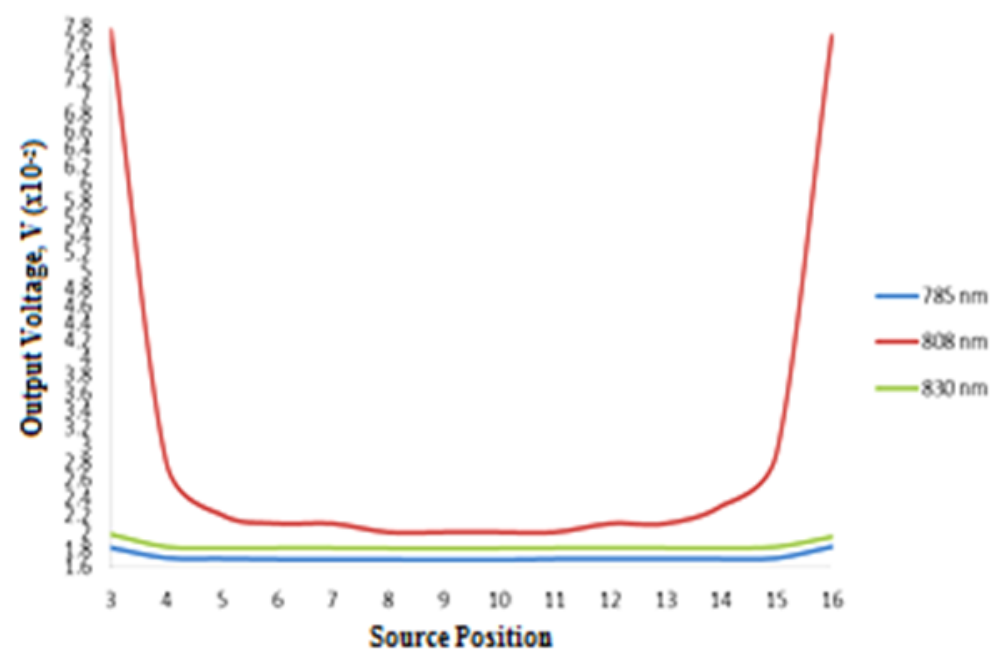

Figure 8. The relationship between output voltage (V) to source position for Sample D + 0.025 gram $\mathrm{TiO}_{2}$ at wavelengths of $780 \mathrm{~nm}, 808 \mathrm{~nm}$ and $830 \mathrm{~nm}$.

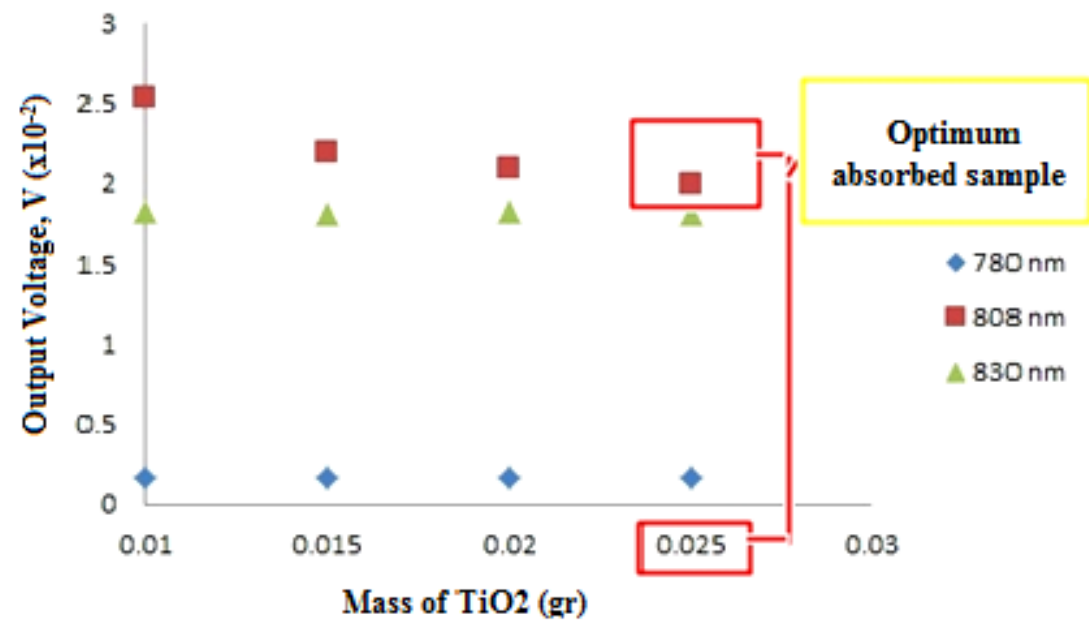

Figure 9. Relationship between transmitted intensity of laser after passing samples as a function mass of $\mathrm{TiO}_{2}$

\subsection{Result of Absorption Coefficient Test}

Figure 10 shows the relationship between transmitted intensity of laser after passing samples as function sample thickness. The absorption coefficient test was only performed on the sample with gelatin-glycerine- $\mathrm{TiO}_{2}$ since the gelatinglycerin sample was a transparent material. The absorption coefficient test results showed that the exponential function equation is $\mathrm{y}=0.365 \mathrm{e}^{-0.167 \mathrm{x}}$. The function $\mathrm{y}$ represents a value of intensity (I) and the 
function $\mathrm{x}$ represents a value of thickness sample. Based on the Lambert-Beer law, the absorption coefficient ( $\mu \mathrm{a})$ of gelatinglycerin- $\mathrm{TiO}_{2}$ phantom at wavelength of 830 $\mathrm{nm}$ is $0.167 \mathrm{~mm}^{-1}$. This value corresponds to the absorption coefficient $\left(\mu_{\mathrm{a}}\right)$ breast at NIR wavelength of $0.1-1 \mathrm{~mm}^{-1}$ (Hielscher, 2002).

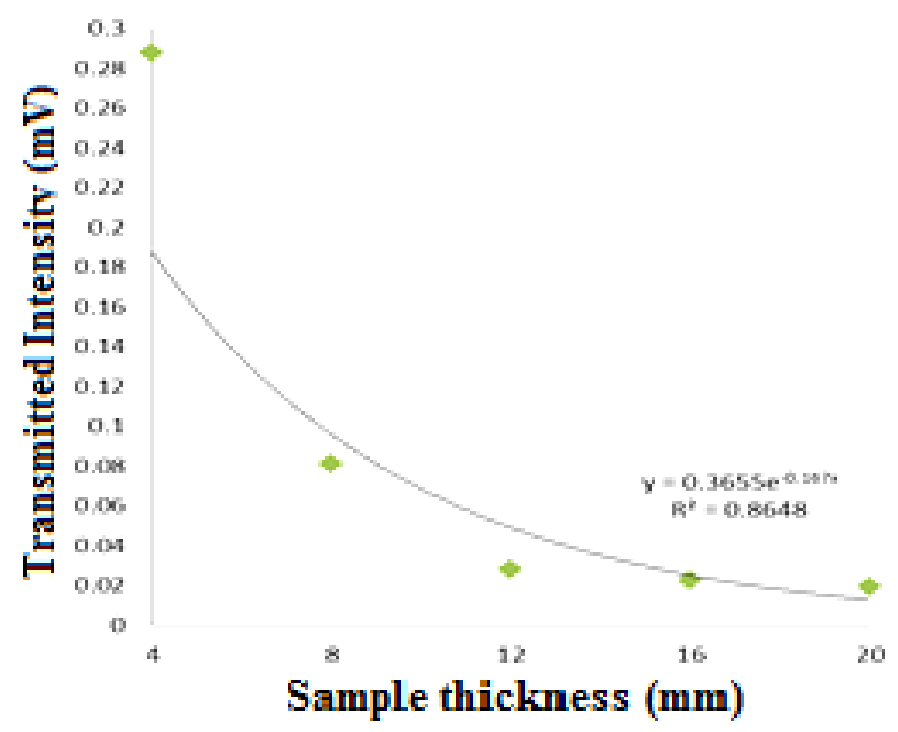

Figure 10. Relationship between transmitted intensity of laser after passing samples as a function sample thickness.

\section{CONCLUSION}

The addition of glycerin in gelatin based phantom composites can increase the durability of the sample. The higher concentration of glycerin added, the more durable the sample are. The most durable sample can be obtained from the addition of glycerin concentration of $100 \%$, which was for 126 hours. The addition $\mathrm{TiO}_{2}$ in gelatin glycerin sample cause gelatin - glycerin sample as the diffuse material. The optimum sample was achieved at wavelength of 830 nm with $\mathrm{TiO}_{2}$ variation of 0.025 grams. When NIR laser with wavelength of $830 \mathrm{~nm}$ and $30 \mathrm{~mW}$ power exposure on this sample, generates the absorption coefficient of 0.167 $\mathrm{mm}^{-1}$. The breast tissue is a diffuse material with absorption coefficient $\left(\mu_{\mathrm{a}}\right)$ at NIR wavelength of $0.1-1 \mathrm{~mm}^{-1}$. So, phantom based on gelatin-glycerin- $\mathrm{TiO}_{2}$ can be applied as material replacement of breast for test object in CW-DOT.

\section{ACKNOWLEDGEMENT}

The authors would like to express their gratitude to the DGHE of Indonesian Government for the support through Universitas Airlangga Research Grant (No. 200/UN3.14/LT/2018). 


\section{REFERENCES}

Azamris (2006) Analisis Faktor Risiko Pada Pasien Kanker Payudara di RS M. Djamil Padang, Jurnal Cermin Dunia Kedokteran 152:53-6.

De Grand A.M., Lomnes S.J., Lee D.S., et al. (2006) Tissue-like phantoms for near-infrared fluorescence imaging system assessment and the training of surgeons, J. Biomed Opt. 2006;11(1):014007.

Heilscher, A.H, A.Y. Bluestone, G.S. Abdoulaev, A.D. Klose, J. Lasker, M. Stewart, U. Netz, dan J. Beuthan (2002) Near-infrared diffuse optical tomography, Disease Markers, 18 (313-337).

Jiang, S., Pogue, B.W., Mc. Bride, T.O., Paulsen, K.D. (2003) Quantitative analysis of near-infrared tomography: sensitivity to the tissuesimulating precalibration phantom, $J$. Biomed Opt. 8 (2), 308-315.

Kemsley E. Kate, Henri S. Tapp, Richard Binns, Robert O. Mackin, Anthony J. Peyton (2008) Feasibility study of NIR diffuse optical tomography on agricultural produce, Journal of Postharvest Biology and technology 48223-230.
Lualdi M., Colombo A., Farina B. and Tomatis S., Marchesini R. ( 2001) A phantom with tissue-like optical properties in the visible and near infrared for use in photomedicine, Lasers in Surgery and Medicine Vol. 28.

McKee, C. T. (2011), Indentation Versus Tensile Measurements of Young's Modulus for Soft Biological Tissues, Tissue Engineering, Part B Volume 17.

N. Ukhrowiyah, D. Kurniadi, Suhariningsih, M. Yasin (2015) Continuous Wave Diffuse Optical Tomography Using Multimode Plastic Fiber for Nondestructive Test of Diffused Material, Optoelectronic and Advanced Material-Rapid Communication,Vol. 9, No. 7-8, p. 995 - 999

Pogue, B.W. and M.S. Patterson (2006) Review of tissue simulating phantoms for optical spectroscopy, imaging and dosimetry, J Biomed Opt. 11(4): p. 041102.

Riset Kesehatan Dasar (2013) Badan Penelitian dan Pengembangan Kesehatan, Kementrian Kesehatan RI, p 38 . 